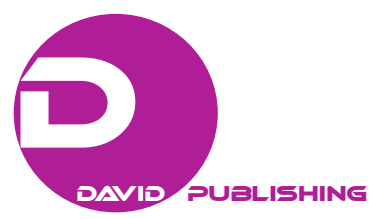

\title{
Representation of Polish Business Groups in the Institutional System of the European Union
}

\author{
Jarosław Filip Czub \\ University of Warsaw, Warsaw, Poland
}

\begin{abstract}
This article is an attempt to present and explain the role played by the Polish business groups in the institutional system of the European Union (EU).This article presents the forms of representing the interests of Polish business groups in the institutional system of the European Union.
\end{abstract}

Keywords: business groups, lobbying, European Union, Poland, European law

\section{Nature of Polish Business Groups}

This article presents the forms of representing the interests of Polish business groups in the institutional system of the European Union. This article is an attempt to present and explain the role played by the Polish business groups in the institutional system of the European Union (EU). The choice of the specific research material is due to several factors. First of all, an analysis of the problem concerning the operation of Polish groups business results from the deficit of research material in the scientific community. Only a few researchers deal with topics related to Polish business organizations in Poland. The most well-known people in Poland include Krzysztof Jasiecki, Malgorzata Molenda-Zdziech, Urszula Kurczewska, Konstanty Adma Wojtaszczyk, Jacek Sroka, Leszek Graniszewski, Artur Nowak-Far, Marcin Michał Wiszowaty and Filip Skawiński ${ }^{1}$. At the international level European interest groups have a much larger number of researchers; however, aside from certain exceptions they do not undertake attempts to verify Polish interest groups in the institutional system of the $\mathrm{EU}^{2}$. The second reason is the fact that Poland currently, from the year 2004, has became the largest member of the EU from among the new member countries of Central and Eastern Europe, and the sixth largest in the EU, which can be of key importance for the development of the region and is gradually becoming a significant actor on the background of the other 28 Member States of the EU. The third reason is the fact that Polish business organizations are often associated with corruption and not with full and legally operating entities that have an impact on EU legislation ${ }^{3}$. Furthermore, it is worth mentioning that Polish business groups have a constructive and significant function in the political system of the European Union (EU). This is particularly visible in the framework of the decision-making process, in which they actively seek to participate. Polish business groups are involved in wider lobbying for other entities, having a significant impact on European Union law and thus have a significant impact on the process of reforming the EU itself and the

\footnotetext{
Jarosław Filip Czub, Ph.D., Institute of European Studies, University of Warsa.

1 Only a few books and articles on Polish interest groups have been published in 2015.

2 Among others: Thierry Lefébure, Conor McGrath, Rinus van Schendelen, Philip Kotler, Koder Collison, Jean-Dominique Giuliani, John Zorack, Bryan Cassidy, Graham Wilson, Joseph H. Kaiser, Gabriel A. Almond, Bing Powell, Bill Coxall, Bernard Le Grelle, Mark Kober-Smith, Justin Greenwood, Karsten Ronit, David Coen, Aynsley Kellow...

${ }^{3}$ Retrieved from http://www.ceo.cxo.pl, http://www5.economist.com
} 
direction of its development.

In accordance with Simon Hix's words, business groups have an important function in all democratic political systems, where they represent the idea of the "civil society" (Hix, 2005, p. 208). Rainer Eising adds that they play a crucial role in the process of mediation between various EU institutions and citizens or economic entities, which they represent at the international level (Eising, 2003, pp. 192-193). Polish business groups mediate between their members or organizations (national confederations ${ }^{4}$ ) and national or European institutions.

In the framework of the research paradigm analysis, such as the process of effective representation of Polish interest groups in the EU, in order to make a thorough explanation I decided to put forward the following research hypothesis:

Referring to the code of conduct adopted by lobbyists, interest groups, including Polish business groups, constitute rightful entities that function within democratic systems, which due to their strong position are capable of active and passive participation in the decision-making process taking place both in the EU and in Poland. Their efficacy depends on the degree of mobilization at the European level, which in turn depends on numerous factors, such as the network of business relations, applied channels of influence or budgets allocated for lobbing campaigns. This hypothesis may be verified with the use of the neofunctional theory, which shows the possibility of participation of business groups in the EU. Neofunctionalism is one of the most important theories used in political science. The aim of these theories is to explain the integration processes taking place in Europe. As such, the theory of neofunctionalism allows for the analysis of activities performed by Polish business groups within the institutional system of the European Union. (Rosamond, 2000, p. 50)

Taking into account the above theory and making an analysis of Polish interest groups as actors affecting legislative changes made in the European Union, the following research questions should be put forth:

Do Polish business groups have a significant impact on the decision-making process of the European Union now and in the past? To what extent do Polish business group contribute to the process of reforming the European Union? Are their lobbying activities active enough that Polish business groups play a significant role in the EU decision making process? Do they adapt to the existing situation and legal regulations? What external factors contribute to the fact that Polish business group could have an impact on the legislative process of the EU? To what extent do Polish business groups affect individual institutions and what determines their activation towards these institutions?

Here, we need to highlight the fact that Polish business groups are often perceived negatively by the society. Such an incorrect perception of their activities contributes to false depiction of Polish business groups operating within the legal framework both at the national and European level. "Truly reliable advocacy of interests is frequently confused with the phenomenon of corruption-generating behaviour and with the use of informal connections" (Czub, 2010, p. 135). Such a general perception of business groups by society causes much controversy. Considering the above, we need to emphasize the fact that Polish business groups are professional and ethical entities, which influence the decision-making processes occurring at various Polish and European institutions. Along with other organisations, reliable Polish business groups may ensure the possibility of dynamic development and economic integration of Poland and the European Union, by maintaining close contact with the European institutions and by using their influence on the decision-making processes taking place in the EU.

\footnotetext{
${ }^{4}$ Members of such organizations include: employers, companies, national federations, other organizations and also members who represent various socio-economic interests.
} 


\section{Origins and Development of Polish Business Groups}

Interest groups started to emerge on Polish lands in the second half of the 19th century. The appearance of such organisations was inspired and caused by the waves of strikes that passed through Europe. Entrepreneurs of Polish origin who lived in territories controlled by the Kingdom of Prussia and Habsburg Austria became involved in the employers' organizations that used to function in those countries. On the other hand, on the lands that belonged to the Russian Empire at that time, a Polish organization - the Union of the Industrialists of the Kingdom of Poland (Związek Przemysłowców Królestwa Polskiego) was established. In such a form, the union operated until 1920. Then, the entrepreneurs' movement was unified by incorporating the employers operating in all territories controlled by the partitioners into the union. As a result, the Central Union of Polish Industry, Mining, Trade and Finance was formed. Until 1947, the primary aim of the union was to represent Polish economic interests. Unfortunately, the organization was disbanded after the first post-war election in 1947, due to political reasons. The representative function on the international forum of the International Labour Organization, co-founded by the Union of the Industrialists of the Kingdom of Poland, was taken over by the officials and managers nominated by the government. In the mid-1980s, private businessmen started to establish economic associations. During that time, the Polish Association of Employers was founded to unify the managers of state-owned companies, while in 1989 the Nationwide Association of Managers was established.

Considering the above, one may see that modern Polish business groups have a relatively short, but rich history of development. Factors that determined the creation of particularistic business organizations were related to the protection and representation of the business environment in the national forum and, later on, on the EU level. On average, the existing Polish business groups have been active for 20 years. It is understandable, considering the fact that the main factor that blocked the creation of such business organizations in Poland was related to the political regime, which effectively impeded the development of Polish entrepreneurships (not to mention the question of representation in the public forum). Therefore, the year 1989 became the main determinant of the creation of Polish business groups. It was the year of political breakthrough, which transformed the centrally planned economy into a free-market economy. The change allowed for the establishment of such groups as: Employers of Poland (Pracodawcy RP-1989), formed as a result of a merge ${ }^{5}$ between various organizations, Polish Bank Association (Zwiazek Banków Polskich-1989), Polish Chamber of Commerce (Krajowa Izba Gospodarcza-1990), Business Centre Club (1991), Polish Business Council (Polska Rada Biznesu-1992) and others.

Polish business groups formed after 1989 became independent, a political organizations with such aims as: protection of the employers' interests and influence on the rapid economic development of Poland, initialization of innovative legal solutions that could allow for the creation of environments favourable towards employers and the pursuit of social peace by harmonizing the trilateral relationships between the government

\footnotetext{
5 The merger took place on 24-25 of November 1989, it was based on the Associations Act and involved the following organizations: Warsaw Economic Association (Warszawskie Towarzystwo Gospodarcze), Polish Association of Employers (Stowarzyszenie Pracodawców w Polsce), Nationwide Association of Managers (Ogólnopolskie Stowarzyszenie Menedżerów), Central Craft Association (Centralny Związek Rzemiosła), Economic Association (Towarzystwo Gospodarcze), National Board of Polish Managers (Krajowa Rada Dyrektorów Polskich) and Association of Industrialists (Towarzystwo Przemysłowców), which first became the founding members of the Confederation of Polish Employers (Konfederacja Pracodawców Polskich), which in June 2010 changed its name to Employers of Poland. Senator Andrzej Machalski became the first president of the Confederation of Polish Employers.
} 
and companies represented by the particularistic organizations. The desire to speak with one voice in particular branches of the economy is another important factor that influenced the establishment of Polish business groups. Creation of such organizations as Polish Chamber of Chemical Industry (Polska Izba Przemystu Chemicznego-1988), Polish Bank Association (Zwiazek Banków Polskich-1989) and Association of Car Dealers (Zwiqzek Dealerów Samochodów-2009) is a good example of this desire. The initiative to represent the interests of particular branches of the economy was one of the determinants of the creation of these associations. Such targeted organizations are focused on the sector lobbing, which limits the area of their operation, but simultaneously increases the chances of achieving their assumed aims in the given area.

Reasons behind the establishment of Polish business groups (conclusion): (1) changes in the Polish political system after 1989; (2) aim - the search for a common platform to share experiences and for univocal representation of common interests; (3) introduction of changes at various levels of economic legislation in 1989; (4) development of corporations, private employers and private initiatives, such as banks with the majority of private capital; (5) stimulation caused by the desire to speak with one voice in particular economic sectors, as in the case of the Association of Car Dealers; and (6) accession of Poland to the EU.

Apart from the widely understood advocacy of interests at the national level, Polish business groups also function in international and European organizations and possess their representative offices in Brussels and at institutions attached to the EU. Associated within BUSINESSEUROPE, the Polish Confederation of Private Employers Lewiatan is a good example of such organization. The Employers of Poland is another fine example of a Polish business group that operates at an international level. The Employers of Poland closely cooperate with various partners from the whole world, such as the International Organisation of Employers (IOE), the International Labour Organization (ILO), the Business and Industry Advisory Committee to the OECD (BIAC) and the European Economic and Social Committee (EESC). This way, they can participate in the works of numerous international organizations and simultaneously develop mutual relations. The Polish Chamber of Commerce is affiliates with the Association of European Chambers of Commerce and Industry (Eurochambres), which represent national chambers of commerce and industry, operating in various EU member states, at the European level. The Polish Bank Association also cooperates in the European forum with the European Banking Federation (EBF), perceived to be the voice of European banks, to protect the banking and financial sectors together with other business entities. The Polish Chamber of Chemical Industry cooperates and lobbies with the European Chemical Industry Council, which represent the chemical industry in the arena of the EU.

The analyses presented above prove that Polish business groups not only operate at the national level, but also lobby in European and international arenas. Therefore, we may conclude that the protection and representation of Polish economic entities performed by Polish business groups takes place not only at the national, but also at the European level. To confirm this fact, we may state that Polish business groups, while representing their members, influence not only Polish legislature, but also international and European (EU) legal systems.

\section{Legal Basis for the Operation of Polish Business Groups}

\section{European (EU) Legal Basis for the Operation of Business Groups}

The institutional system of the European Union is open to various interest groups, Polish business groups included. When the European Coal and Steel Community (ECSC) was established in 1951, its aim was to build a united Europe by ensuring close cooperation with "political actors" only. Art. 5 of the Treaty establishing the 
European Coal and Steel Community reads as follows: "The Community shall accomplish its mission, under the conditions provided for in the present Treaty, with limited direct intervention. To this end, the Community will: enlighten and facilitate the action of the interested parties by collecting information, organizing consultations and defining general objectives; place financial means at the disposal of enterprises for their investments and participate in the expenses of readaptation; ...". In 1958, a year after the Treaty of Rome was signed, the European Commission issued an announcement that confirmed only the possibility for establishing cooperation and holding consultation with interest groups (Cini, 2005, pp. 197-198). The Treaty establishing the European Economic Community does not contain any legal regulation related to interest groups. Only art. 118 speaks about "... close collaboration between Member States in the social field...". On the other hand, art. 229 states that the Commission shall be responsible for ensuring all suitable contacts with international organizations, and in accordance with art. 245, par. 2 of the Treaty establishing the European Economic Community, the Commission is entitled and obliged to contact governments and interest groups. The Single European Act contains provisions related to cooperation in the area of science and technical development between Member States of the European Community and international organizations and third-party states - the European Union indirectly perceives interest groups as international organizations (Cini, 2005). The Treaty on European Union (Maastricht Treaty) regulated the issues related to interest groups more strictly. Provisions of the Treaty are focused mainly on social issues. Interest groups gained the right of initiative and the opportunity to actively create social policy within the European Union, while the European Commission could expand the scale of communication with interest groups as far as this policy is concerned. Provisions of the Amsterdam Treaty allowed for the improvement of social dialogue (art. 136-148 in particular) ${ }^{6}$. Solutions proposed in the Treaty make it possible to establish close cooperation between Member States, conduct research, exchange opinions and hold consultations in the area of internal and foreign policies, especially with international organizations. The Treaty of Nice and the Treaty of Lisbon increase the possibilities for establishing cooperation between the European Union and various interest groups, especially those that represent the interests of employers and employees ${ }^{7}$.

Moreover, the European Commission created a register of interest and business groups and the code of conduct for lobbyists. The register was established on 23 June 2008 for a trial period of one calendar year ${ }^{8}$. Due to the fact that the endeavour helped to increase the transparency of lobbying activities, the Commission decided to extend it for the following years, until 22 July 2011, when a common register was established in cooperation with the European Parliament (The EP had maintained a separate register of interest groups) ${ }^{9}$. In order to improve the transparency of representing interests at the European level, the European Parliament and the European Commission decided to establish the "Transparency Register" of organizations and self-employed

\footnotetext{
${ }^{6}$ Art. 136-148 in particular mention this.

7 The issue is discussed especially in the Treaty on the Functioning of the European Union, art. 154 (former art. 138 of the Treaty on European Union), art. 11 (former art. 6 of the Treaty on European Union), art. 207 (former art. 133 of the Treaty establishing the European Economic Community). The chronological outline of cooperation with social partners looks as follows: 2 December 1992: Communication from the Commission: An Open and Structured Dialogue between the Commission and Special interest groups-93/C63/02; 25 July 2001: European governance-A white paper-COM (2001) 428; 3 May 2006: Green Paper "European Transparency Initiative"-COM (2006) 194; 21 March 2007: Communication from the Commission: Follow-up to the Green Paper "European Transparency Initiative"-COM (2007) 127; 27 May 2008: "European Transparency Initiative: A framework for relations with interest representatives (Register and Code of Conduct)"-COM (2008) 323; 28 October 2009: "Transparency Initiative: the Register of Interest Representatives, one year after"- COM (2009) 612.

${ }^{8}$ Retrieved from http://www.webgate.ec.europa.eu

${ }^{9}$ Retrieved from http://www.europarl.europa.eu
} 
persons involved in the development and implementation of the European Union policy, accompanied by the code of conduct for interest groups (applicable in communication with institutions, authorities, officials and the EU). Over 9200 interest groups ${ }^{10}$ operating in various sectors have been registered so far. Moreover, business groups are now able to express their opinions and consult the EC about various issues through the EC website "Your Voice in Europe"". The register is voluntary, but the situation may change, especially after March 2011, when journalists of "Sunday Times" organized a provocative corruption scandal in the EP. Considering the above, apart from the aforementioned legal regulations, business groups performing their activities at the European level have to observe the following articles of particular treaties: the Treaty of Lisbon amending the Treaty on European Union and the Treaty establishing the European Community, signed at Lisbon, 13 December 2007 - consolidated version (art. 11, 13) and consolidated version of the Treaty on the Functioning of the European Union (art. 154, 163, 207, 300).

To conclude, the European Union does not impose any strict regulations related to lobbying activities. Only the postulates presented above, to some extent, regulate the lobbying operations performed at the European level. It means that as far as the legitimization of lobbying at the European level is concerned, there is still much to be done in order to incorporate the activities performed by various business groups into specific legal framework at the EU level.

\section{Polish Legal Basis for the Operation of Business Groups}

Legal basis related to the operation of Polish business groups is determined by the Constitution of the Republic of Poland and Convention for the Protection of Human Rights and Fundamental Freedoms ${ }^{12}$. In particular, art. 12 ensures "... freedom for the creation and functioning of trade unions, socio-occupational organizations of farmers, societies, citizens' movements, other voluntary associations and foundations". Moreover, art. 58, par. 1 of the Constitution states that "the freedom of association shall be guaranteed to everyone" and art. 59, par. 1 emphasizes "the freedom of association ... in employers' organizations". The preamble to the Constitution refers also to social dialogue, which Polish business groups take active part in as social partners. The preamble defines social dialogue as “... the basic law for the State". Art. 20 emphasizes the role of dialogue and cooperation with social partners. The Tripartite Commission for Socio-Economic Affairs (Trójstronna Komisja ds. Społeczno-Gospodarczych) is the most fundamental Polish institution related to social dialogue. The Commission allows for the creation of favourable conditions for a dialogue between three parties: government, trade unions and employers' organizations. It makes it possible to reach a compromise between the parties, especially between employers, employees and the government. Apart from the Constitution, the activities performed by Polish business groups are subject to the following Polish legal acts: (1) The act of 23 May 1991 on trade unions ${ }^{13}$; (2) The act of 30 May 1989 on chambers of commerce ${ }^{14}$; and (3) The act of 7 July

\footnotetext{
${ }^{10}$ As on 19 February 2016; we need to highlight the fact that until 29 August 2008, only 291 interest groups have been registered. Therefore, we may conclude that the register improves the transparency, that the number of officially registered business organizations is rapidly increasing and that this tendency is constant (Retrieved from http://www.europa.eu).

11 Retrieved from http://www.euractiv.com, www.ec.europa.eu

12 Constitution of the Republic of Poland of 2 April, 1997, adopted by the National Assembly of Poland on 2 April 1997, approved by a national referendum on 25 May 1997 and signed by the President of Poland on 16 July 1997, published in Journal of Laws No. 78, item 483 (art. 12, 57-59, 191 in particular) (Dz.U. 1997 nr 78 poz. 483, Dz.U. Nr 61, poz. 284 z późn. zm). Retrieved from http://www.treaties.un.org, http://www.conventions.coe.int

${ }^{13}$ Dz. U. Nr 55, poz. 235 z późn. zm

14 Dz. U. Nr 35, poz. 195 z późn. zm
} 
2005 on lobbying activity in the lawmaking process, Law amending the Law on the Council of Ministers and certain other acts ${ }^{15}$.

\section{Specificity of Polish Business Groups}

Polish business groups represent various interests at the national and European levels. The character of most such organizations is economic. They constitute the biggest and most diverse group among all other forms of interest groups. Their primary aim in Poland and in the European Union is to advocate their interests in the economic sector. The attention of these organizations is focused mainly on economic and financial aspects. The criteria for categorization of such groups made it possible to classify them into particular blocks. Polish business organizations can be categorized as follows ${ }^{16}$ : (1) general profile (multi-sectoral) - economic activity that involves all economic sectors-multi-sectoral economic business organizations: Polish Confederation of Private Employers Lewiatan (Polska Konfederacja Pracodawców Prywatnych Lewiatan), Polish Business Council (Polska Rada Biznesu), Polish Chamber of Commerce (Krajowa Izba Gospodarcza), Employers of Poland (Pracodawcy Rzeczypospolitej Polskiej), Business Centre Club (BCC), Polish Business Club (Polski Klub Biznesu), Polish Organization of Business and Entrepreneurship (Polska Organizacja Biznesu $i$ Przedsiębiorczości).

(2) industry profile (sectoral) — economic activity limited to a single sector-specialized economic business organizations: Polish Bank Association (Zwiqzek Banków Polskich), Association of Car Dealers (Zwiazek Dealerów Samochodów), Polish Organization of Trade and Distribution (Polska Organizacja Handlu i Dystrybucji), Polish Franchise Organization (Polska Organizacja Franczyzodawców), Polish Chamber of Chemical Industry (Polska Izba Przemystu Chemicznego), Railway Business Forum.

To conclude, we may state that the specificity of Polish business groups depends on their multi-sectoral or industry profile and on their particularistic interests related to the economic aspects they represent. The expertise and lobbying activities performed by such organizations constitute a valuable source for their members and for the officials working at various national and European institutions. Their primary aims involve the performance of lobbying, representative and educational activities that influence the process of Polish and European integration and economic development.

Table 1

Characteristics of Selected Polish Economic Business Groups Operating in Poland and in the EU

\begin{tabular}{|l|l|l|}
\hline $\begin{array}{l}\text { Business } \\
\text { group } \\
\text { type }\end{array}$ & $\begin{array}{l}\text { Name of the } \\
\text { organization }\end{array}$ & Character of the organization \\
\hline $\begin{array}{l}\text { The Polish } \\
\text { Confederation } \\
\text { of Private } \\
\text { Employers } \\
\text { Lewiatan } \\
\text { PKPP } \\
\text { Lewiatan) }\end{array}$ & $\begin{array}{l}\text { Established on 7 January 1999. Regional and sectoral structures of PKPP Lewiatan include over } \\
\text { 3500 companies that employ over 600 thousand people. The organization is a member of the Tripartite } \\
\text { Commission for Socio-Economic Affairs. It is an affiliate of the BUSINESSEUROPE (UNICE) } \\
\text { organization, which represents the interests of entrepreneurs and employers at the European } \\
\text { Commission, European Parliament and other institutions of the EU. It effectively influences the } \\
\text { lawmaking process, soliciting for more favourable legislation for Polish entrepreneurs and looking } \\
\text { after their image. It monitors the barriers encountered by the entrepreneurs and performs their own } \\
\text { macroeconomic analyses }{ }^{17} \text {. }\end{array}$ \\
\hline
\end{tabular}

\footnotetext{
15 Dz.U. z 2009 r. Nr 42, poz. 337

16 The criterion for categorization is based on assumptions that depend on the type of activity performed by the given business group (general and specialized profiles of economic business groups).

17 Retrieved from http://www.pkpplewiatan.pl
} 
(Table 1 continued)

\begin{tabular}{|c|c|c|}
\hline $\begin{array}{l}\text { Business } \\
\text { group } \\
\text { type }\end{array}$ & $\begin{array}{l}\text { Name of the } \\
\text { organization }\end{array}$ & Character of the organization \\
\hline \multirow{4}{*}{ Economic } & $\begin{array}{l}\text { The } \\
\text { Employers of } \\
\text { Poland (PRP) }\end{array}$ & $\begin{array}{l}\text { Established on } 24 \text { November } 1989 \text { (as the Confederation of Polish Employers), the organization has } \\
\text { been operating under its current name since } 15 \text { June } 2010 \text {. The Employers of Poland (formerly: } \\
\text { Confederation of Polish Employers) is the biggest and the oldest employers' organization in Poland. It } \\
\text { was established in November } 1989 \text { and represents over } 7000 \text { companies: from small entrepreneurships } \\
\text { to the biggest corporations in the country-able to effectively compete in international markets. The } \\
\text { companies affiliated with the Employers of Poland employ app. } 3 \text { million employees. Most of them- } \\
85 \% \text {--are private companies. The Employers of Poland actively participate in: Parliament proceedings } \\
\text { and Senate commissions, decision-making processes and consultations at various levels of state } \\
\text { administration and in the committees that control and monitor the use of EU funds. They participate in } \\
\text { the Tripartite Commission for Socio-Economic Affairs. The organization cooperates with partners from } \\
\text { all over the world, participates in the works of numerous international organizations and develops } \\
\text { mutual relations with them. It is a member of the International Organisation of Employers (IOE), the } \\
\text { International Labour Organization (ILO), the Business and Industry Advisory Committee to the OECD } \\
\text { (BIAC) and the European Economic and Social Committee (EESC) }\end{array}$ \\
\hline & $\begin{array}{l}\text { Polish } \\
\text { Chamber of } \\
\text { Commerce } \\
\text { (KIG) }\end{array}$ & $\begin{array}{l}\text { Established on } 13 \text { February 1990. The Polish Chamber of Commerce is the biggest independent } \\
\text { business organization in Poland. It represents the largest number of entrepreneurs, associating over } 150 \\
\text { business organizations. The Polish Chamber of Commerce promotes social sensitivity in business. It } \\
\text { organizes trainings and conferences and assists entrepreneurs in the implementation of ethical } \\
\text { standards. The most socially sensitive companies are awarded within the "Fair Play Company" } \\
\text { ("Przedsiębiorstwo Fair Play") programme. } \\
\text { The Polish Chamber of Commerce looks after Polish entrepreneurs in the international arena. KIG is a } \\
\text { member of the Association of European Chambers of Commerce and Industry (Eurochambres) and the } \\
\text { International Chamber of Commerce in Paris. It signed cooperation agreements with most national chambers } \\
\text { of commerce in the world. Its actions are aimed at the improvement of Poland's image in the world }{ }^{19} \text {. }\end{array}$ \\
\hline & $\begin{array}{l}\text { Polish } \\
\text { Business } \\
\text { Council } \\
\text { (PRB) }\end{array}$ & $\begin{array}{l}\text { Established on } 30 \text { May 1992. The association is apolitical and its members can be the owners or } \\
\text { management board presidents of large Polish private companies or foreign companies which operate in } \\
\text { Poland, meet the membership requirements and express the will to become involved in the works of } \\
\text { the association. PRB is a "lobby", a pressure group and an external force that is willing to influence } \\
\text { people responsible for making decisions. Members of PRB want to change society's stereotypical } \\
\text { perception of capitalists by the society... inculcate employees with a modern way of thinking about } \\
\text { their employers... They cooperate with the US Business Round Table, which associates the presidents } \\
\text { or CEOs of the } 200 \text { biggest American companies... }{ }^{20} \text {. }\end{array}$ \\
\hline & $\begin{array}{l}\text { Business } \\
\text { Centre Club } \\
\text { (BCC) }\end{array}$ & $\begin{array}{l}\text { Established in 1991, the BCC is a prestigious club of entrepreneurs and the biggest organization of } \\
\text { individual employers in Poland. It has } 2500 \text { members (natural persons and companies). Representing } \\
\text { almost } 250 \text { cities, the members of the BCC are associated in } 24 \text { regional lodges all over Poland. } \\
\text { Representatives of all sectors, international corporations, financial and insurance institutions, } \\
\text { telecommunication companies, the biggest Polish producers, universities, publishing houses and } \\
\text { well-known law firms belong to the BCC. Economic lobbying activities performed by the BCC are } \\
\text { focused on the development of free-market economy, creation of favourable legal regulations and } \\
\text { Protection of Polish entrepreneurs' interests. Experts affiliated with the BCC co-create and evaluate } \\
\text { economic law, participate in the works of Parliament commissions as well as persuade ministers and MPs } \\
\text { to their solutions. The BCC represents the employers' interests in the Tripartite Commission for } \\
\text { Socio-Economic Affairs and, as the employers' association, has influence on the most important social } \\
\text { and economic matters in Poland: it participates in works on budget legislation, negotiates the provisions } \\
\text { of collective labour agreements with the representatives of trade unions, evaluates legal acts and bills, } \\
\text { asks the Constitutional Tribunal to verify compliance of legal acts and regulations with the constitution, } \\
\text { influences the officials of public administration, local authorities, Parliament and Senate on issues related } \\
\text { to the protection of economic interests of its members, takes legal actions related to petitions, criminal } \\
\text { proceedings, private prosecution and participates in on-going legal actions for the benefit of its members. } \\
\text { The BCC is an international organization, awarded at the European Parliament with the EESC's award for } \\
\text { its significant contribution in the promotion of European integration and identity }{ }^{21} \text {. }\end{array}$ \\
\hline
\end{tabular}

${ }_{18}$ Retrieved from http://www.pracodawcyrp.pl

19 Retrieved from http://www.kig.pl

${ }^{20}$ Retrieved from http://www.prb.pl

${ }^{21}$ Retrieved from http://www.bcc.org.pl 
(Table 1 continued)

\begin{tabular}{|c|c|c|}
\hline \begin{tabular}{|l} 
Business \\
group \\
type
\end{tabular} & $\begin{array}{l}\text { Name of the } \\
\text { organization }\end{array}$ & Character of the organization \\
\hline Economic & $\begin{array}{l}\text { Polish } \\
\text { Business } \\
\text { Club (PKB) }\end{array}$ & $\begin{array}{l}\text { Established in 1990. A public benefit organization. The oldest independent business organization } \\
\text { associating private entrepreneurs in Poland. It promotes Polish economy, companies and people who } \\
\text { want to implement European business models and meet standards established in the developed part of } \\
\text { Europe. It presents the opinions of the environment, mainly on conditions related to business activities. } \\
\text { PKB is a member of the European organization "Club of Europe". Its actions are aimed at the creation } \\
\text { of new economic reality in Poland and integration with the EU } 22 \text {. }\end{array}$ \\
\hline \multirow{4}{*}{$\begin{array}{l}\text { Industry } \\
\text { profile }\end{array}$} & $\begin{array}{l}\text { Polish Bank } \\
\text { Association } \\
(\mathrm{ZBP})\end{array}$ & $\begin{array}{l}\text { Established on } 30 \text { May 1989. The Polish Bank Association is a self-governing organization of banks. } \\
\text { Membership in ZBP is voluntary and covers banks that operate in the Republic of Poland, established } \\
\text { and functioning on the basis of Polish law. Members of the association may also be the departments of } \\
\text { loan institutions or foreign banks that operate in the territory of Poland in accordance with Polish law. } \\
\text { ZBP associates } 58 \text { banks of general character and } 54 \text { cooperative banks. The aim of problem solving } \\
\text { teams, committees, councils, committees and subcommittees that act within the association is to } \\
\text { develop and express opinions on matters crucial for the operation of the Polish banking system. They } \\
\text { also integrate the banking environment around common endeavours. ZBP represents the Polish } \\
\text { banking sector abroad, participating in the works of the European Banking Federation (EBF), } \\
\text { International Chamber of Commerce, European Committee for Banking Standards, International } \\
\text { Banking Security Association and European Payments Council. On behalf of the latter, it coordinates } \\
\text { the works aimed at the implementation of the Single Euro Payments Area (SEPA) in Poland }{ }^{23} \text {. }\end{array}$ \\
\hline & $\begin{array}{l}\text { Association } \\
\text { of Car } \\
\text { Dealers } \\
(\text { ZDS })\end{array}$ & $\begin{array}{l}\text { Established on } 25 \text { September 2009. ZDS is an employers' association. Its primary aims include } \\
\text { effective representation of the interests of Polish car dealers in relations with national authorities and } \\
\text { car selling concerns. Members of the association include } 120 \text { dealers that represent over } 32 \text { percent of } \\
\text { car market in Poland. Two permanent working groups operate within the association: "Finances" and } \\
\text { "Insurance and loss settlement". The purpose of these working groups is to develop the most } \\
\text { favourable solutions related to cooperation with dealer market suppliers and to perform common } \\
\text { activities aimed at the improvement of legal regulations related to the operations of a particular } \\
\text { working group. In order to solve the problems occurring in other areas of contact with the suppliers, } \\
\text { other working groups are established } a d \text { hoc }^{24} \text {. }\end{array}$ \\
\hline & $\begin{array}{l}\text { Polish } \\
\text { Chamber of } \\
\text { Chemical } \\
\text { Industry } \\
\text { (PIPC) }\end{array}$ & $\begin{array}{l}\text { Established in 1988. PIPC is an organization that represents the chemical industry in national } \\
\text { administrative institutions and international organizations. The chamber associates several dozens of } \\
\text { the biggest production and trade companies, research institutes and industry associations. It supports } \\
\text { economic initiatives and implementation of legal solutions aimed at the comprehensive development of } \\
\text { the chemical industry in Poland and in the whole world. So far, the activities of the organization, } \\
\text { especially in the area of integration of the chemical industry, has been focused on the representation of } \\
\text { the chemical sector in administrative institutions, employee-related issues, health and safety, } \\
\text { environmental protection, transport, legislative solutions and on the process of accession of Poland to } \\
\text { the European Union. For many years PIPC has been cooperating with the European Chemical Industry } \\
\text { Council - CEFIC. It is the only Polish institution that is an actual member of CEFIC. Due to that fact, } \\
\text { it is entitled to represent the Polish chemical industry in the international forum }{ }^{25} \text {. }\end{array}$ \\
\hline & $\begin{array}{l}\text { Railway } \\
\text { Business } \\
\text { Forum (RBF) }\end{array}$ & $\begin{array}{l}\text { Established in 2000. The organization associates almost } 80 \text { companies of huge potential and } \\
\text { importance for the Polish railway market. RBF is an association of employers. Its most fundamental } \\
\text { task is to protect the rights of its members and to represent them in relations with the employees' trade } \\
\text { unions and state, administrative and local authorities. RBF's mission is to organize debates and panel } \\
\text { discussions, sponsor conferences, decide about the publication of announcements, appeals, letters and } \\
\text { opinions, participate in the Parliament and Senate sessions and public discussions in media, cooperate } \\
\text { with such European organizations as: UNIFE-Association of the European Railway Industries and } \\
\text { national organizations such as: "Pro-Rail Alliance"-Allianz pro Schiene from Germany }{ }^{26} \text {. }\end{array}$ \\
\hline
\end{tabular}

\footnotetext{
${ }^{22}$ Retrieved from http://www.plbclub.pl

${ }^{23}$ Retrieved from http://www.zbp.pl

24 Retrieved from http://www.zds.org.pl

${ }_{25}$ Retrieved from Retrieved from http://www.pipc.org.pl

${ }^{26}$ Retrieved from Retrieved from http://www.rbf.net.pl
} 


\section{Effects of the Operations Performed by Polish Business Groups}

In functional terms, lobbying performed by Polish business organizations is constantly being developed. Despite the short period of their activity, Polish business groups managed to conduct some successful lobbying campaigns. The campaign organized in 2006 to provide strawberry producers with EU subsidies may be a good example here. Referred to as the "fruit lobbying", the campaign turned out to be a success of the Association of Polish Orchardists (Zwiazek Sadowników RP-ZSRP) ${ }^{27}$. It was inspired by the negative situation in the fruit processing market. The organization decided to protect Polish producers of fruits. The unfavourable situation was caused by erroneous negotiations related to horticulture and vegetable growing, held during the process of accession of Poland to the EU. It was so serious that several months after the accession, Polish farmers organized a protest at the Ministry of Agriculture. Ryszard Kaźmierczak, president of the Association of Polish Orchardists, highlighted the fact that this protest "was not against any particular minister or authorities, but was caused by the omnipresent poverty of the farmers". The protests were organized in Warsaw and in other regions of Poland. The main aim of the campaign was to financially support the processing fruit industry and producers of such fruits as: strawberries, raspberries, currants (black and red), gooseberries, cherries (sweet and sour) and apples. The association looked for help mainly abroad (due to the fact that the support for the association's initiatives appeared in Poland only when the problems were given publicity in the media). It entered into cooperation with industry organizations. The association decided that the best solution at the supranational level was to look for supporters who could help to promote appropriate postulates. Therefore, the Association of Polish Orchardists supported the postulates proposed by the French and Italians, who in turn supported the Polish initiative. The association sent its representatives to the EU to present the postulates related to the stabilization of the soft fruit market. Moreover, the association supported the representatives of the EC by co-organizing their visits. The aim of such visits was to produce a report related to the situation of the aforementioned fruits in the Polish market. Simultaneously, along with the progressing works on the EC's report, the association initiated actions that were aimed at convincing members of the Committee on Agriculture and members of the European Parliament to recognize Polish postulates related to the stabilization of this market in the EU. During the visit of the Committee's delegates, the association presented the problems of their industry and emphasized the necessity for changes in the EU system. Due to the insightful presentation, the representatives of the EP, including Joseph Daul, president of the European Parliament at that time, started to perceive Polish postulates with more approval and understanding. Next, a decision was made to prepare a resolution on the stabilization of the market of soft fruits and cherries. The project was developed by the Association of Polish Orchardists and included the following postulates: implementation of the mechanisms supporting the processing fruits market (subsidies per kilogram of fruits delivered to the producer by producers' groups), protection of the European market against fruits imported from third-party states and increase of funding for producers' groups operating in new member states. In order to support these postulates, the Association of Polish Orchardists organized a delegation to Brussels attended by: Ryszard Kaźmierczak, Sławomir Łuczak and Leszek Przybytniak. The delegation was organized by a member of the European Parliament, Bogdan Golik. Its aim was to "accelerate the works on the reform of the EU market of fruits and vegetables". The representatives of the Association of Polish Orchardists met with people responsible for the European farming policy, including Commissioner Marianne Fischer Boel and President Joseph Daul. Another

\footnotetext{
${ }^{27}$ Retrieved from http://www.sadownictwo.com.pl
} 
meeting with Daul was held in Strasburg. During both meetings, the association was reassured about the support for the proposals presented in the resolution and about the positive conduct of the vote in the Commission.

Eventually, the whole action turned out to be a success. The assumed demands of the association were met and were as follows: (1) The EC accepted the anti-dumping duty (ad valorem) proposal for frozen strawberries imported from China at the session of the Anti-dumping Committee held on 10 October 2006. "The duty rate applicable so far was increased by the value of anti-dumping duty in the amount of $34.2 \%$ of the product price"; and (2) Another effect was the "introduction of additional subsidies for farmers growing strawberries and raspberries". The European Commission recognized the arguments of the Association of Polish Orchardists. In the end, the subsidy programme covered farmers who grow fruits (including strawberries) in the area of at least 0.1 ha (10 acres).

Such actions prove that lobbying activities performed by Polish business groups can be effective. The most crucial requirements that need to be fulfilled by Polish business groups to ensure the success of their campaigns include the preparation of reliable documentation and analyses, performance of effective lobbying activities and monitoring of on-going works. The abovementioned example illustrates the fact that lobbying operations performed by Polish business groups can produce the assumed results through great determination, the will to protect their members' postulates and strong argumentation. Moreover, it proves that in its functional dimension, Polish lobbying is becoming more visible and that its strictly legitimized activity will be less and less associated with the phenomenon of the corruption-generating dealings.

\section{Conclusion}

The article attempts to demonstrate that Polish business groups, constitute rightful entities that function within democratic systems, which due to their strong position are capable of active and passive participation in the decision-making process taking place both in the EU and in Poland. Their efficacy depends on the degree of mobilization at the European level, which in turn depends on numerous factors, such as the network of business relations, applied channels of influence or budgets allocated for lobbing campaigns. The following arguments speak for these statements: (1) Polish business group are official entities participating in European social dialogue, and by issuing opinions and providing consultation they have an impact on the creation of EU policies and its further development as well as integration in the socio-economic sphere; (2) Polish business group act as a liaison, an indirect link of cooperation and representation of particular interests of specific socio-economic groups in the EU; (3) Polish business groups are strategic centres of expertise for officials and EU institutions; (4) The specificity of the Polish business groups highlights the differences between the fractions, parties and business groups, influencing the decision-making process; (5) The role of Polish business groups, through their demonstrated compromises, is crucial for the economies of Member States; (6) The successive stages of political, economic and social integration at the EU level have an impact on the development of Polish business groups, by creating new policies, institutional changes and the moving borders of the EU; and (7) The activity of Polish business groups is seen as a corruptive phenomenon in Poland due to the lack of proper knowledge and certain officials abusing their competences.

The role of Polish groups business amounts to mediation, representation and consultation. Behind the scenes in the European Parliament there is talk about the fifth power in the EU and the fifth power may just be Polish business groups, which by their representation play intermediary, consultative and educational roles in 
the creation and implementation of national and EU legislation. Thus directly and indirectly they contribute to the construction of a strong EU internal market and deepening the integration process of the European Union. The expanding legitimacy of the EU gives Polish groups business more consultation opportunities and the Treaty of Lisbon has strengthened the possibility of mediation by business groups through broader social dialogue.

\section{References}

Cassidy, B. (1999). European lobbying guide-A guide on whom and how to lobby. London: Hawksmere.

Cini, M. (2005). European Union politics. New York: Oxford University Press.

COM. (2006). 194 wersja ostateczna.

Coxall, B. (2001). Pressure groups in British politics. Harlow: Pearson Education Limited.

Czub, J. F. (2010). Reprezentacja polskich grup biznesowych $w$ systemie instytucjonalnym Unii Europejskiej a rzetelne rzecznictwo interesów. Przegląd Politologiczny. No. 4.

Czub, J. F., (2012). Lobbing grup biznesu w Unii Europejskiej. Warszawa: Wydawnictwo Poltext.

Ehrlich, S. (1962). Grupy nacisku w strukturze politycznej kapitalizmu. Warszawa: Państwowe Wydawnictwo Naukowe.

Eising, R. (2003). Interest groups and the European Union. In M. Cini (Ed.), European Union politics (pp. 192-193). Oxford: Oxford University Press.

European Commission. (2012). Zielona Księga Europejska Inicjatywa Na Rzecz Przejrzystości. May 2006. Retrieved January 8 , 2012, from http://ec.europa.eu/transparency/eti/docs/gp_pl.pdf.

Gazeta podatnika. (2011). Wzrost wynagrodzeń budżetówki tylko o 3 procent. Retrieved January 10, 2014, from http://www.gazetapodatnika.pl/artykuly/pracodawcy_wzrost_wynagrodzen_budzetowki_tylko_o_23_proc-a_11885.htm

Goergen, P. (2006). Lobbying in Brussels. Brussels: D \&P Service.

Góralczyk, W., \& Sawicki, S. (2010). Prawo międzynarodowe publiczne w zarysie. In R. Bierzanek \& J. Symonides (Eds.), Prawo międzynarodowe publiczne (pp. 360-374). Warszawa: LexisNexis.

Graniszewski, L., \& Piątkowski, C. (2004). Grupy interesu w Unii Europejskiej. Warszawa: Wydawnictwo Sejmowe.

Hix, S. (2005). The political system of the European Union (2nd ed.). Basingstoke, Hampshire, New York, London: Palgrave.

Jasiecki, K., Molęda-Zdziech, M., \& Kurczewska, U. (2000). Lobbing. Sztuka skutecznego wywierania wptywu. Kraków: Oficyna Ekonomiczna.

Le Grelle, B. (1988). Profession lobbyman: Le pouvoir des coulisses. Paris: Hachette.

Matyja, M. (2000). Wplyw Zrzeszenia Konfederacji Przemysłowców i Pracodawców Europy (UNICE) na proces decyzyjny w Unii Europejskiej. Warszawa: Scholar.

Olson, M. (1965). The logic of collective action: Public goods and the theory of groups (Revised edition ed.). Cambridge-Massachusetts-London: Harvard University Press.

Rosamont, B. (2000). Theories of European Integration. New York: Palgrave Macmillan.

Sejm Rzeczypospolitej Polskiej. (2005). Lobbing. Retrieved January 8, 2012, from http://orka.sejm.gov.pl/SQL.nsf/lob?OpenAgent\&wykazl

Sejm Rzeczypospolitej Polskiej. (2005). Lobbing $i$ wystuchanie publiczne. Retrieved January 10, 2012, from http://www.sejm.gov.pl/lobbing/lobbing1.html

Sejm Rzeczypospolitej Polskiej. (2005). Ustawa O Działalności Lobbingowej W Procesie Stanowienia Prawa. July 2005. (Dz.U. z 2005 r. $\mathrm{Nr} 169$, poz. 1414, z późn. Zm). Retrieved January 10, 2012, from http://www.sejm.gov.pl/prawo/lobbing/lobbing.htm

Sroka, J. (2000). Europejskie stosunki przemysłowe w perspektywie porównawczej. Wrocław: Wydawnictwo Uniwersytetu Wrocławskiego.

Sroka, J. (2009). Lobbing jako strategia promocji interesów grupowych. In W. A. Jabłoński \& L. Sobkowiak (Eds.), Marketing polityczny w teorii i praktyce (pp. 208-209). Wrocław: Wydawnictwo Uniwersytetu Wrocławskiego.

Van Schendelen, R. (2005). Machiavelli in Brussels, The Art of Lobbying the EU. Amsterdam: Amsterdam University Press.

Vipond, P. (1995). European Banking and insurance, business alliances and corporate strategies. In J. Greenwood (Ed.), European casebook on business alliances (p. 101). Hemel Hempstead: Prentice-Hall.

Zorack, J. L. (1990). The lobbying handbook. Washington : Beacham Pub. 